\title{
Non-Target Lesion Worsening Indicator
}

National Cancer Institute

\section{Source}

National Cancer Institute. Non-Target Lesion Worsening Indicator. NCI Thesaurus. Code C142364.

An indication as to whether a non-target lesion is showing signs of worsening. 